\title{
Intensive land-based production of red and green macroalgae for human consumption in the Pacific Northwest: an evaluation of seasonal growth, yield, nutritional composition, and contaminant levels
}

\author{
Bradley A. Gadberry ${ }^{1}$, John Colt ${ }^{1, *}$, Desmond Maynard ${ }^{1}$, Diane C. Boratyn ${ }^{2}$, Ken Webb $^{1,3}$, \\ Ronald B. Johnson ${ }^{1}$, Gary W. Saunders ${ }^{4}$ and Richard H. Boyer ${ }^{1}$ \\ ${ }^{1}$ Environmental and Fisheries Sciences, Northwest Fisheries Science Center, National Marine Fisheries Service, NOAA, 2725 \\ Montlake Blvd. E, Seattle, WA 98112, USA \\ ${ }^{2}$ Sol-Sea Ltd., 700 NW 42nd Street, Suite 415, Seattle, WA 98107, USA \\ ${ }^{3}$ University of Texas Marine Science Institute, 750 Channelview Drive, Port Aransas, TX 78373, USA \\ ${ }^{4}$ Centre for Environmental and Molecular Algal Research, Department of Biology, University of New Brunswick, PO Box \\ 4400, Fredericton, NB, E3B 5A3, Canada
}

Turkish towel (Chondracanthus exasperatus), Pacific dulse (Palmaria mollis, also known as Red ribbon seaweed), and sea lettuce (Ulva spp.) were cultivated in a land-based intensive culture system at the Manchester Research Station, USA from August 2013 to September 2014. Macroalgae were grown in tumble-aerated tanks, harvested bimonthly for seasonal growth calculations, and analyzed for protein, lipid, ash, and amino acid content. Growth rate of all three species exhibited a similar pattern, with the highest specific growth rates occurring during the summer months (Turkish towel: $7.8 \%$, Pacific dulse: $8.2 \%$, and sea lettuce: $6.2 \%$ ). Growth of all three species was lowest around winter solstice; with negative growth only observed in sea lettuce. On a dry weight basis significant differences in protein content existed between the three species with highest values for sea lettuce $(29.5 \pm 1.4 \%)$. Lipid content varied between species $(0.95-2.78 \%)$ with significantly higher lipid observed in sea lettuce (0.58-4.82\%). No significant differences were detected on a seasonal basis among each species. Essential amino acids accounted for $43 \pm 0.9$ to $47 \pm 1.2 \%$ of total amino acids with Turkish towel having the highest value. Turkish towel had a significantly higher taurine level $(0.82 \pm 0.27)$ than the other macroalgae. The levels of persistent organic pollutants and heavy metals were low. The estimated annual product of the three species ranged from 50- to 70-mt dry weight ha $\mathrm{y}^{-1} \mathrm{y}^{1}$, significantly higher than conventional crops. Land-based culture of these species can produce year-round harvest, consistent product quality, and low contaminant levels.

Key Words: contaminants; land-based culture; macroalgae; proximate composition \footnotetext{
(c) (9) $\$$ This is an Open Access article distributed under the mercial License (http://creativecommons.org/licenses/by-nc/3.0/) which permits unrestricted non-commercial use, distribution, and reproduction in any medium, provided the original work is properly cited.
}

Received September 20, 2017, Accepted February 21, 2018

*Corresponding Author

E-mail: john.colt@noaa.gov

Tel: +1-206-860-3243, Fax: +1-206-860-3267 


\section{INTRODUCTION}

World macroalgal production is a $\$ 6$ billion (USD) industry and most is used for human food products (McHugh 2003) and produced from aquaculture (Food and Agriculture Organization of the United Nations 2014). In 2012, China and Indonesia accounted for $81 \%$ of global cultivated macroalgal production (Food and Agriculture Organization of the United Nations 2014). Production of macroalgae in the United States is located on the East Coast, California, and Hawaii and contributes only $1 \%$ to total global seaweed production.

Land-based macroalgal culture avoids many regulatory and permitting issues associated with water-based systems, reduces conflicts with other near-shore users, allows precise control of the rearing environment, and reduces harvesting and management costs (Bidwell et al. 1985, Pereira et al. 2013, Kim and Yarish 2014). The integration of macroalgal culture to treat the discharge from land-based finfish systems can reduce energy and nutrient requirements, reduce nutrient discharges to the environment, and provide additional revenue (Buschmann et al. 1994, Abreu et al. 2009).

Macroalgae can be grown at densities ranging from 3-10 $\mathrm{kg} \mathrm{m}^{-2}$ using compressed air to rotate the macroalgae (Huguenin 1976, Craigie and Shacklock 1995). Macroalgae growth depends primarily on light, nutrients, and inorganic carbon (total alkalinity and $\mathrm{pH}$ ). With a well-designed fertilization program and adequate water flows to maintain inorganic carbon, macroalgal growth is controlled primarily by light levels and to lesser degree by salinity and temperature (Demetropoulos and Langdon 2004a).

The chemical composition of wild macroalgae, their nutritional composition, and health benefits to humans has been widely studied (Fleurence 1999, MacArtain et al. 2007, Cornish and Garbary 2010). However, very little information is available on the chemical composition and growth rate of land-based farmed macroalgae with adequate nutrients levels. Most land-based macroalgae studies have focused on the use of macroalgae to remove nutrients from finfish or in integrated multi-trophic aquaculture (IMTA) applications. Due to season variation in nutrient excretion rates, it is likely that both the chemical composition and growth rates of macroalgae were adversely impacted by suboptimal nutrient levels over some portion of the year.

The objective of this study was to evaluate seasonal changes in growth rate, yield, chemical composition, and contaminant levels in three species of Pacific Northwest macroalgae: Turkish towel (Chondracanthus exasperates (Harvey \& Bailey) Hughey), Pacific dulse (Palmaria mollis (Setchell \& Gardner) van der Meer \& Bird), and sea lettuce (Ulva spp.) grown in a land-based system. This basic information is necessary to support development of commercial land-based macroalgal aquaculture for human food products.

\section{MATERIALS AND METHODS}

\section{Culture and sampling methods}

Turkish towel and sea lettuce were obtained from SolSea Ltd., Port Orchard, Washington. The Pacific dulse was obtained from the Mukilteo Research Station, Mukilteo, Washington from a stock originally collected from Fidalgo Island, Washington by Chris Langdon at Oregon State University (Rosen et al. 2000). The Turkish towel and Pacific dulse had been vegetatively propagated for at least $10 \mathrm{y}$ in these land-based systems. The macroalgae were cultured outside in six fiberglass tanks, two replicates per species, at the Manchester Research Station, Port Orchard, Washington for a 12-month experimental growth trial from August 2013 to August 2014.

The culture tanks were $1.5 \mathrm{~m}$ by $4.6 \mathrm{~m}$ with rounded bottoms and rounded ends. The volume and surface area at the water surface were 2.27 and $2.10 \mathrm{~m}^{2}$, respectively. A perforated polyvinyl chloride pipe was installed on the bottom of the tank along the longitudinal axis. Low-pressure air was used to tumble the macroalgae (Huguenin 1976). The water flow was $14.1 \pm 3.7 \mathrm{~L} \mathrm{~min}^{-1}$ for a mean hydraulic residence time of $161 \mathrm{~min}$ and 8.9 turnovers $\mathrm{d}^{-1}$. The tanks had an internal screened discharge that was controlled by an external overflow standpipe. The water supply for this experiment was effluent from a landbased flow-through system for the rearing of finfish. The seawater supply to the finfish facility was treated by rapid sand filtration, and ultraviolet disinfection (Maynard et al. 2012).

Turkish towel and sea lettuce were pulse fertilized twice a week with $54 \mathrm{~g}$ ammonium sulfate $\left(5.00 \mathrm{mg} \mathrm{L}^{-1}\right.$ as $\mathrm{N}$ ) and $26 \mathrm{~g}$ triple super phosphate (1.11 $\mathrm{mg} \mathrm{L}^{-1}$ as $\left.\mathrm{P}\right)$. For the Pacific dulse, $73 \mathrm{~g}$ calcium nitrate $\left(5.00 \mathrm{mg} \mathrm{L}^{-1}\right.$ as $\mathrm{N}$ ) was substituted for the ammonium sulfate because of potential ammonia toxicity issues (Demetropoulos and Langdon 2004b). Based on an influent ammonia-nitrogen concentration of 20-30 $\mu \mathrm{M}$ (Waaland 2004), 70-100\% of the nitrogen requirement of macroalgae was provide by finfish. The purpose of the fertilizer addition was to 
ensure that nitrogen was provided in excess. Effluent nutrient concentrations were not monitored. A f/2 trace metals stock solution (Guillard and Ryther 1962) was added once a week $\left(200 \mathrm{~mL} \mathrm{tank}^{-1}\right)$.

All macroalgae were removed from experimental tanks, and weighed approximately every 14-15 days. The macroalgae were drained for 30-60 min and weighed on a hanging scale (Model SB8; Amtek Chatillon Scales, Largo, FL, USA). Starting weights for each tank were then readjusted to 4 or $4.11 \mathrm{~kg} \mathrm{~m}^{-2}$ (9.08 $\left.\mathrm{kg} \mathrm{tank}^{-1}\right)$ after every sampling. During sampling, the tanks were drained and cleaned prior to refilling. After weighing, obvious nontarget macroalgal species were removed.

A single representative sample (400-500 g) was taken from each tank, rinsed with seawater to remove any sand, debris, or extraneous matter and sealed in plastic bags to be transported to a laboratory for analysis. Excess water was removed using a salad spinner. Samples were then weighed and oven dried. Dried samples were ground into a fine powder and packed in airtight jars. Samples were stored in a $-20^{\circ} \mathrm{C}$ freezer until analysis. Nutrient analysis of macroalgae was carried out in duplicate, except for crude lipid due to its low lipid content.

\section{Sampling plan}

Proximate analysis of the macroalgae was conducted on a monthly basis for each tank, resulting in 12 samples per tank and 24 samples per species. Amino acid analysis was conducted quarterly in each tank, resulting in 4 samples per tank and 8 samples per species. Persistent organic pollutants (POPs) and metals analysis was conducted in a single tank quarterly, resulting in two samples tank $^{-1}$ and four samples per species.

\section{Growth rate}

The specific growth rate (SGR, \% wet weight $\mathrm{d}^{-1}$ ) between sampling dates was calculated using the following formula:

$$
\mathrm{SGR}=\left[\frac{\ln \left(\mathrm{W}_{\mathrm{f}}\right)-\ln \left(\mathrm{W}_{\mathrm{i}}\right)}{\mathrm{t}}\right] \times 100
$$

, where $\mathrm{W}_{\mathrm{f}}$ and $\mathrm{W}_{\mathrm{i}}$ are final and initial weights and $\mathrm{t}$ is the growth period. The SGR was computed for each tank at each weighing interval, resulting in 24 SGR measurements for the annual cycle.

In addition, the yield ( $\mathrm{kg}$ wet weight $\mathrm{d}^{-1} \mathrm{~m}^{-2}$ ) was computed from:

$$
\text { Yield }=\left[\frac{\left(\mathrm{W}_{\mathrm{f}}-\mathrm{W}_{\mathrm{i}}\right)}{\mathrm{t} \times \mathrm{SA}}\right]
$$

, where SA is the surface area of the rearing vessel $\left(\mathrm{m}^{2}\right)$.

\section{Chemical analysis of macroalgae}

Dry weight analysis. Dry weight of macroalgae was determined by using AOAC Method 952.08 (AOAC International 2005) using a drying temperature of $105^{\circ} \mathrm{C}$. This drying temperature may not be appropriate for analysis of fatty acids, vitamins, and phytochemicals (Chan et al. 1997, Gupta et al. 2011).

Protein analysis. Crude protein content was determined using the Dumas method, AOAC Method 968.06 (AOAC International 2005). A LECO FP-2000 Nitrogen Analyzer (LECO Corporation, St. Joseph, MI, USA) was used to determine the nitrogen content of macroalgae. Percent protein was then determined by multiplying percent nitrogen by a factor of 6.25 (Mariotti et al. 2008). While this factor over-estimates the true protein content of macroalgae, it is used to allow direct comparison with other commercial feed components. In addition, a specific protein / nitrogen factor was computed for each species as the sum of the individual amino acid residues (molecular weight of each amino acid less the molecular weight of water) and the nitrogen content (Food and Agriculture Organization of the United Nations 2003).

Crude lipid content analysis. Crude lipid was extracted from powder samples using Soxhlet extraction, AOAC Method 920.39 (AOAC International 2005). In particular, lipids were extracted from $3 \mathrm{~g}$ samples using a Buchi 810 Soxhlet Fat Extraction Apparatus (Flawil, Switzerland) with dichloromethane as the solvent.

Ash content analysis. Ash content was determined via AOAC Method 942.05 (AOAC International 2005). Samples (1 g) were ashed overnight in a muffle furnace at $550^{\circ} \mathrm{C}$.

Amino acids analysis. Total amino acid profiles were analyzed by the Agricultural Experiment Station Chemical Laboratories (ESCL), University of Missouri-Columbia according to AOAC Method 982.30 (AOAC International 2005).

Heavy metal analysis. Arsenic, lead, and cadmium were analyzed by the ESCL, University of Missouri-Columbia according to AOAC Method 990.08 (AOAC International 2005).

Persistent organic pollutants. Wet samples of macroalgae were extracted and analyzed for POPs using the gas chromatography / mass spectrometry method of 
Sloan et al. (2006, 2014). Sum PCBs ( $\sum$ PCBs) includes the summed concentrations of congeners $17,18,28,31$, $33,44,49,52,66,70,74,82,87,95,99,101 / 90,105,110$, $118,128,138 / 163 / 164,149,151,153 / 132,156,158,170$, $171,177,180,183,187 / 159 / 182,191,194,195,199,205$, 206, 208, and 209. Sum DDTs (EDDTs) is the sum of o,p'DDD, p, $\mathrm{p}^{\prime}$-DDD, o, $\mathrm{p}^{\prime}$-DDE, p, $\mathrm{p}^{\prime}$-DDE, o, $\mathrm{p}^{\prime}$-DDT, and p, $\mathrm{p}^{\prime}$ DDT. Sum chlordanes ( $\Sigma$ CHLDs) is the summed levels of heptachlor, heptachlor epoxide, oxychlordane, gammachlordane, nona-III-chlordane, alpha-chlordane, transnonachlor, and cis-nonachlor. Sum of the hexachlorocyclohexanes ( $\mathrm{HHCHs}$ ) includes summed concentrations of aHCB, bHCH, and lindane (gHCH). Sum of polybrominated diphenyl ethers ( $\angle \mathrm{PBDEs}$ ) is the summed levels PBDEs 28, 47, 49, 66, 85, 99, 100, 153, 154, 155, and 183. Additional POPs analyzed in the current study include hexachlorobenzene, aldrin, dieldrin, mirex, and endosulfan.

\section{Taxonomic identification of macroalgae}

During the study, samples were collected and stored at $-20^{\circ} \mathrm{C}$. At the end of the experiment, samples were freezedried and ground. A total of 20 specimens were assessed for their genetic identity. Samples were dried in silica and the DNA extracted as outlined in Saunders and McDevit (2012). For the chlorophycean green algae the marker tufA was amplified, while the rhodophycean specimens (Chondracanthus and Palmaria) had COI-5P or the alternate marker $r b c \mathrm{~L}-3 \mathrm{P}$ (when COI-5P failed) amplified, all following Saunders and Moore (2013). Data for the chlorophycean marker tufA was assigned to a species based on BLAST searches at NCBI (http://www.ncbi.nlm.nih. gov), while both rhodophycean markers were searched through BOLD (http://www.boldsystems.org).

\section{Environmental monitoring}

Water temperature was recorded every $30 \mathrm{~min}$ in each tank over the entire experiment using $64 \mathrm{k}$ Hobo pendant loggers (Onset, Bourne, MA, USA). Monthly salinity information was obtained from Sinclair Inlet (latitude, 47.5500; longitude, -122.6417), a Washington Department of Ecology monitoring site approximately $10 \mathrm{~km}$ to the east of the Manchester Field Station (Department of Ecology, Marine Water Monitoring 2017). Day length information was obtained from Timeanddate.com (2014).

\section{Statistical analysis}

Statistical analyses for growth, nutrient composition, and heavy metals results were performed with $\mathrm{R}$ ver. 3.4.3 statistical software (The R Foundation for Statistical Computing, Vienna, Austria). A mean SGR (Eq. 1) and yield (Eq. 2) was computed for each algae species from two replicate tanks at each semi-monthly weighing interval, resulting in 24 SGR and yield measurements, per species for the annual cycle. Friedman's rank sum test for non-parametric repeated measures was employed to detect differences between algal species over the annual cycle. The Nemenyi multiple comparison test was used as a post hoc test to detect differences between algal SGR means.

One-way analysis of variance (ANOVA) was employed to detect differences in nutrient composition, protein / nitrogen ratios, and heavy metal concentrations between algal species over the annual cycle. In addition, within a species, proximate composition results were grouped by season, resulting in 6 samples per species, per season. One-way ANOVA was then employed to detect differences in protein, lipid, and ash content of each species

Table 1. Water temperature $\left({ }^{\circ} \mathrm{C}\right)$ for tanks and species

\begin{tabular}{|c|c|c|c|c|c|c|c|c|c|}
\hline \multirow[b]{2}{*}{ Parameter } & \multicolumn{6}{|c|}{ Tank value } & \multicolumn{3}{|c|}{ Mean species value } \\
\hline & $\begin{array}{l}\text { Tank } 3 \\
\text { (dulse) }\end{array}$ & $\begin{array}{l}\text { Tank } 6 \\
\text { (dulse) }\end{array}$ & $\begin{array}{c}\text { Tank } 1 \\
\text { (Turkish) }\end{array}$ & $\begin{array}{c}\text { Tank } 5 \\
\text { (Turkish) }\end{array}$ & $\begin{array}{c}\text { Tank } 2 \\
\text { (sea lettuce) }\end{array}$ & $\begin{array}{c}\text { Tank } 4 \\
\text { (sea lettuce) }\end{array}$ & $\begin{array}{c}\text { Tanks 3, } 6 \\
\text { (dulse) }\end{array}$ & $\begin{array}{l}\text { Tanks 1, } 5 \\
\text { (Turkish) }\end{array}$ & $\begin{array}{c}\text { Tanks } 2,4 \\
\text { (sea lettuce) }\end{array}$ \\
\hline Mean \pm SD & $9.93 \pm 1.63$ & $10.26 \pm 1.63$ & $10.27 \pm 1.80$ & $10.32 \pm 2.02$ & $10.29 \pm 1.78$ & $10.62 \pm 2.75$ & $10.10 \pm 1.74$ & $10.30 \pm 1.86$ & $10.45 \pm 2.15$ \\
\hline Maximum & 13.63 & 14.17 & 14.42 & 17.23 & 14.80 & 17.73 & 13.90 & 14.23 & 16.05 \\
\hline Minimum & 5.95 & 6.78 & 6.59 & 4.87 & 6.66 & 6.15 & 6.36 & 5.73 & 6.40 \\
\hline Range & 7.68 & 7.39 & 7.83 & 12.36 & 8.14 & 11.58 & 7.53 & 8.50 & 9.65 \\
\hline $\mathrm{r}^{2}\left(\mathrm{~T}_{\mathrm{av}}\right.$ vs. $\left.\mathrm{G}\right)$ & 0.225 & 0.193 & 0.295 & 0.237 & 0.039 & 0.207 & 0.261 & 0.269 & 0.121 \\
\hline $\mathrm{r}^{2}\left(\mathrm{~T}_{\mathrm{av}}\right.$ vs. DL) & 0.447 & 0.543 & 0.553 & 0.441 & 0.374 & 0.335 & 0.503 & 0.508 & 0.345 \\
\hline
\end{tabular}

Values are based on mean daily temperatures collected in individual tanks and computed from temperatures recorded every 30 min over the entire experiment. $T_{a v}$ is the average water temperature for each growth period. The $r^{2}$ parameters are the linear regression fits for $T_{a v}$ versus specific growth rate ( $T_{a v}$ vs. G) and $T_{a v}$ versus day length ( $T_{a v}$ vs. DL). SD, standard deviation $(n=2)$. 
attributable to season. Differences detected by ANOVA comparisons were deemed significant at the $p<0.05$ level. When a significant difference was detected, Tukey's honest significant difference (HSD) analysis was used as a post hoc test to determine the relationships between means.

Average daily water temperatures were computed for each tank and for each growth period; both tank and species averages were computed. Average day lengths were computed for each growth period. Linear regressions between SGRs and day lengths and other parameters were done using Microsoft EXCEL (Redmond, WA, USA). For water temperatures, regression equation and coefficient were computed for both tank values and species values.

\section{RESULTS}

\section{Environmental conditions}

Information on the water temperatures is presented in Table 1 for the individual rearing tanks and species averages $(n=2)$. The temperature ranged from $4-6^{\circ} \mathrm{C}$ in the winter to $14-17^{\circ} \mathrm{C}$ in the summer. The salinity at Sinclair Inlet was $28.9 \pm 0.8 \mathrm{psu}$. The day length varied from 8 to $16 \mathrm{~h}$ over the year.

\section{Specific growth rate}

The mean SGR (\% wet weight $\mathrm{d}^{-1}$ ) of the three species is shown in Fig. 1 on a bimonthly basis and in Table 2 on an annual basis. The mean SGRs for the three species were significantly $(\mathrm{p} \leq 0.03)$ different (Pacific dulse $>$ Turkish towel $>$ sea lettuce). With the exception of two measurements for sea lettuce in December, the SGRs were positive over the whole year. The peak growth rates occurred near the summer solstice and lowest growth rates near the winter solstice. The SGRs were highly correlated $\left(r^{2}=0.69-0.86\right)$ with day length (Fig. 2$)$. This indicates that growth rate is strongly function of ambient light levels. There was a weak correlation between individual temperatures and SGR values $\left(\mathrm{r}^{2}=0.04-0.23\right)$ and a moderate correlation between temperature and day length $\left(\mathrm{r}^{2}\right.$ $=0.34-0.55$ ) (Table 1). The $\mathrm{r}^{2}$ value for salinity and mean SGR ranged from 0.14 to 0.29 .

On Dec 31, 2013, Tank 4 overflowed and an unknown amount of sea lettuce was lost. On Apr 4, 2014, the effluent screen was dislodged and all the sea lettuce was lost from Tank 2. This tank was restocked from macroalgae harvested from Tanks 2 and 4 on Mar 31, 2014 and stored

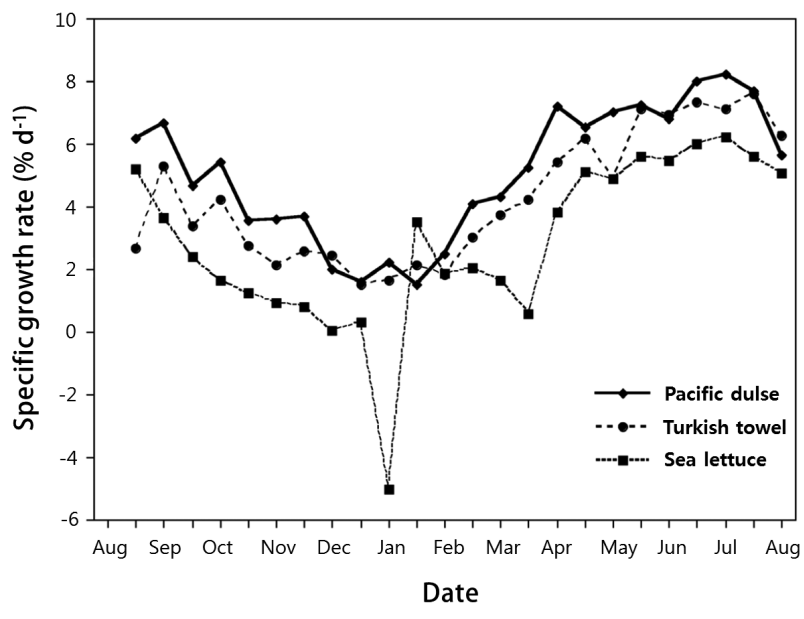

Fig. 1. Mean specific growth rate $\left(\%\right.$ wet weight $\left.d^{-1}\right)$ of macroalgae from August 2013 to August 2014.

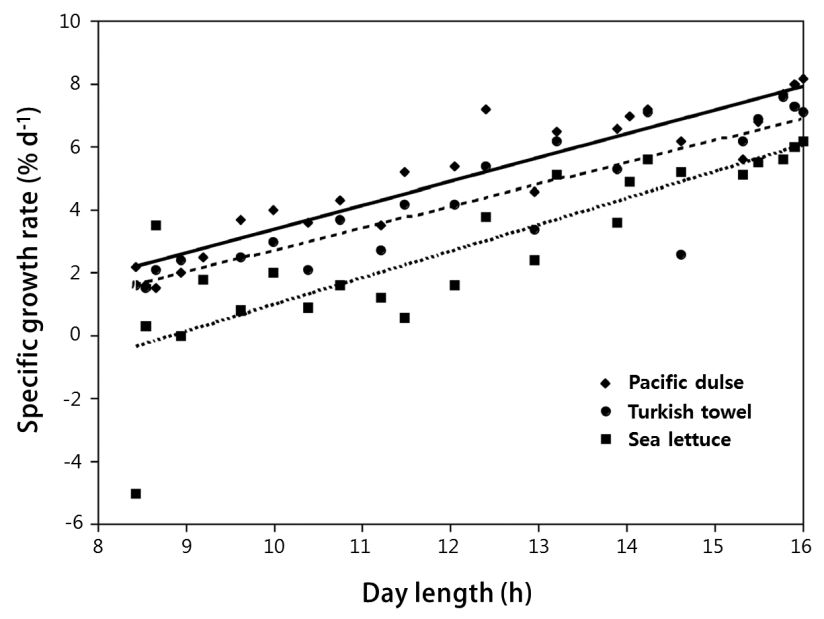

Fig. 2. Specific growth rate (\% wet weight $\left.d^{-1}\right)$ as a function of day length from August 2013 to August 2014.

Table 2. Mean annual specific growth rate (SGR, \% wet weight $\mathrm{d}^{-1}$ ) of Pacific dulse, Turkish towel, and sea lettuce

\begin{tabular}{lccccc}
\hline \multicolumn{1}{c}{ Species } & Tank & n & \multicolumn{1}{c}{ SGR } & Max & Min \\
\hline Pacific dulse & 3,6 & 48 & $5.0 \pm 2.1$ & 8.2 & 1.5 \\
Turkish towel & 1,5 & 48 & $4.2 \pm 2.1$ & 7.6 & 1.5 \\
Sea lettuce & 2,4 & 48 & $2.8 \pm 2.6$ & 6.2 & -5.0 \\
Pacific dulse & 3 & 24 & $4.9 \pm 2.6$ & 8.4 & 0.6 \\
& 6 & 24 & $5.19 \pm 1.9$ & 8.7 & 2.4 \\
Turkish towel & 1 & 24 & $4.4 \pm 2.1$ & 7.7 & 1.4 \\
& 5 & 24 & $4.1 \pm 2.2$ & 7.5 & 1.2 \\
Sea lettuce & 2 & 24 & $2.8 \pm 2.9$ & 6.7 & -5.2 \\
& 4 & 24 & $2.9 \pm 2.8$ & 7.2 & -4.9 \\
\hline
\end{tabular}

Values of SGR are presented as mean \pm standard deviation. $\mathrm{n}$, the number of replicates; Max, maximum; Min, minimum. 
in a refrigerator.

At the start of the experiment, some unidentified amphipods were observed in the dulse tanks. As the experiment progressed, the macroalgae were free of macroinvertebrates such as amphipods, caprellids, mussels, barnacles, snails, and sea squirts.

The Turkish towel tanks were almost entirely free of other macroalgal species ( 0.0 to $0.24 \%$ by wet weight). The levels of contamination in the sea lettuce $(0.0$ to $8.95 \%$ by wet weight) and Pacific dulse tanks ( 0.0 to $5.19 \%$ by wet weight) were highly variable. The primary contaminants in the dulse tanks were green macroalgae and in the sea lettuce tanks, filamentous diatoms.

Determining sample weighs presented operational problems in this work (10-30 $\left.\mathrm{kg} \mathrm{tank}^{-1}\right)$. The Pacific dulse drains rapidly when placed on racks or in draining baskets. The Turkish towel needed to be turned or rotated to allow water to drain. The weighing of the sea lettuce presented the greatest challenge due to the thin sheet morphology. When spread on draining racks, the top portion could start to desiccate while bottom portion could still be saturated with water. It was necessary to repeatedly turn this macroalgae over on the drying racks. As a result, the precision of the growth rate data for the sea lettuce may be less than for Pacific dulse or Turkish towel.

\section{Yields}

The mean yields ( $\mathrm{kg}$ wet weight $\mathrm{m}^{-2}$ ) for the three species are shown in Fig. 3 on a bimonthly basis. The mean yields for the three species were significantly ( $p \leq 0.03$ ) different (Pacific dulse $>$ Turkish towel $>$ sea lettuce). The yields were positively correlated with day length and in two out of three species, the regression coefficients for yield vs. day length were higher than for SGR vs day length.

\section{Proximate analysis}

No seasonal differences were found for protein, lipid, ash, or dry weight for the three species (Table 3). On an annual basis, sea lettuce had a significantly higher protein $(29.5 \pm 1.4 \%)$ and lipid content $(2.97 \pm 1.0 \%)$ than Pacific dulse or Turkish towel (Fig. 4). Pacific dulse had a significantly higher ash content (42\%) than sea lettuce (32\%) or Turkish towel (36.5\%).

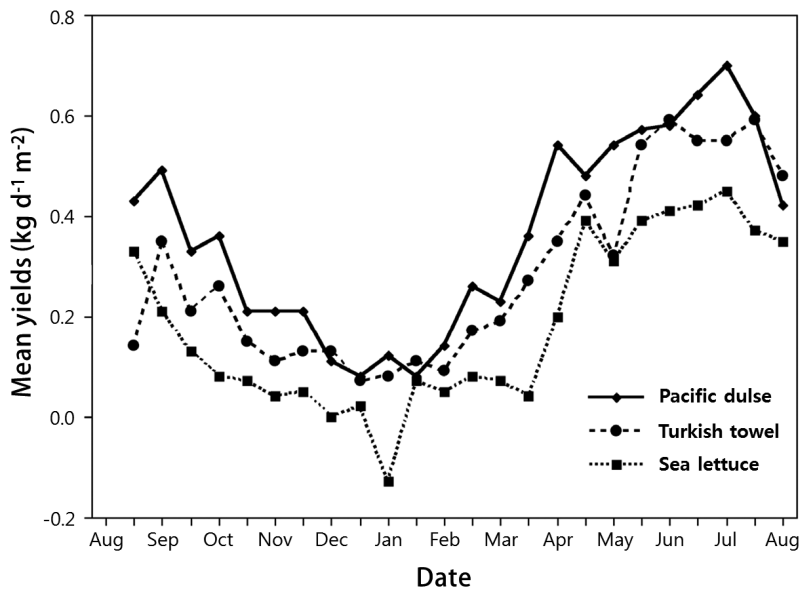

Fig. 3. Yield of macroalgae from August 2013 to August 2014.
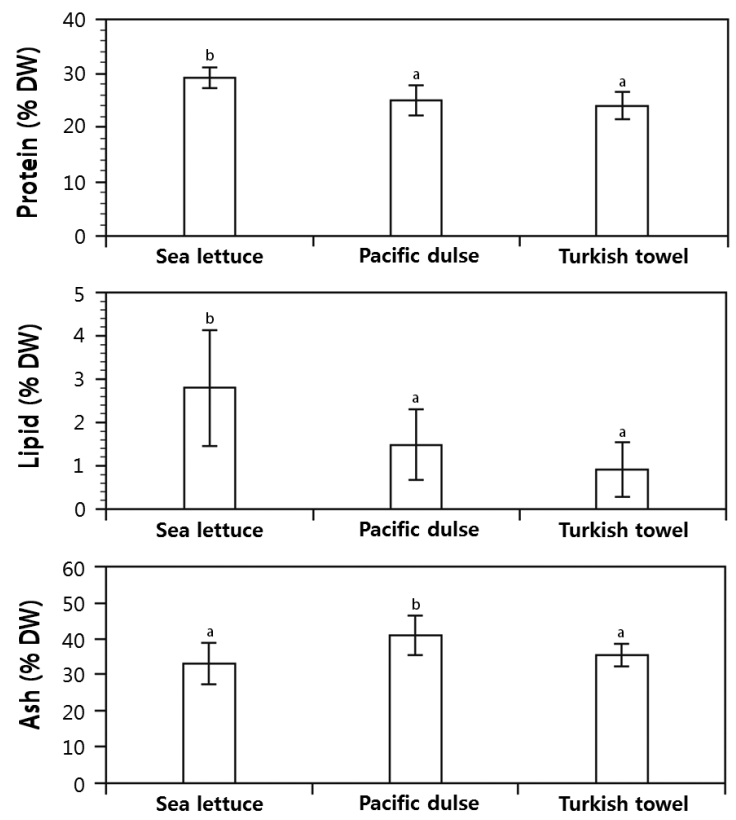

Fig. 4. Annual protein, lipid, and ash values expressed as percent dry weight (mean \pm standard deviation, $n=48$ ). Values within a panel with different superscripts are significantly different $(p<0.05)$.

\section{Amino acid analysis}

The amino acid profiles (g amino acids $100 \mathrm{~g}^{-1}$ dry macroalgae) of the three species of seaweeds are presented in Table 4. Turkish towel $(47.0 \pm 1.2 \%)$ contained significantly more essential amino acids than Pacific dulse $(45.3 \pm 0.8 \%)$ or sea lettuce $(43.0 \pm 0.9 \%)$. Based on the mean values for the three species, the highest content of essential amino acids were leucine (1.70), valine (1.41), and arginine (1.29) and the lowest content were methio- 
nine (0.43), histidine (0.38), and tryptophan (0.24). The highest content of non-essential amino acids was aspartic acid (2.85), glutamic acid (2.66), and alanine (1.79). Taurine, a sulfonic acid was found to have a significantly higher concentration in Turkish towel $(0.82 \pm 0.27)$ than in both sea lettuce $(0.12 \pm 0.05)$ and Pacific dulse $(0.10 \pm$ 0.02).

\section{Protein / nitrogen ratios}

The protein / nitrogen ratios are presented in Table 5. The protein / nitrogen ratio for Pacific dulse was significantly larger than for Turkish towel but not significantly different for sea lettuce. The conventional value for the protein / nitrogen ratio is 6.25 (Mariotti et al. 2008).

\section{Heavy metals}

The arsenic, cadmium, and lead content macroalgae are presented in Table 6 in terms of $\mathrm{mg} \mathrm{kg}^{-1}$ dry weight. There were no significant differences between the species for cadmium or lead. The lead content was very low; none of the samples were greater than the level of detection. The arsenic content of the farmed Turkish towel (11.0 $\mathrm{mg} \mathrm{kg}^{-1}$ ) was significantly higher than the Pacific dulse $\left(5.5 \mathrm{mg} \mathrm{kg}^{-1}\right)$ or sea lettuce $\left(5.8 \mathrm{mg} \mathrm{kg}^{-1}\right)$.
Table 4. Amino acid composition in $\mathrm{g}$ total amino acids $\left(100 \mathrm{~g}^{-1}\right.$ dry macroalgae)

\begin{tabular}{|c|c|c|c|}
\hline Component & $\begin{array}{l}\text { Pacific } \\
\text { dulse }\end{array}$ & $\begin{array}{c}\text { Turkish } \\
\text { towel }\end{array}$ & $\begin{array}{c}\text { Sea } \\
\text { lettuce }\end{array}$ \\
\hline \multicolumn{4}{|l|}{ Essential amino acids } \\
\hline Arginine & $1.29 \pm 0.06$ & $1.35 \pm 0.08$ & $1.23 \pm 0.13$ \\
\hline Histidine & $0.39 \pm 0.03$ & $0.40 \pm 0.03$ & $0.35 \pm 0.06$ \\
\hline Isoleucine & $1.02 \pm 0.06$ & $1.03 \pm 0.07$ & $1.02 \pm 0.06$ \\
\hline Leucine & $1.67 \pm 0.08^{\mathrm{a}}$ & $1.61 \pm 0.11^{\mathrm{a}}$ & $1.82 \pm 0.14^{\mathrm{b}}$ \\
\hline Lysine & $1.32 \pm 0.11^{\mathrm{c}}$ & $1.18 \pm 0.08^{\mathrm{b}}$ & $1.01 \pm 0.07^{\mathrm{a}}$ \\
\hline Methionine & $0.42 \pm 0.02^{\mathrm{ab}}$ & $0.39 \pm 0.04^{\mathrm{a}}$ & $0.47 \pm 0.04^{\mathrm{b}}$ \\
\hline Phenylalanine & $1.07 \pm 0.07^{\mathrm{a}}$ & $1.02 \pm 0.10^{\mathrm{a}}$ & $1.32 \pm 0.09^{\mathrm{b}}$ \\
\hline Threonine & $1.12 \pm 0.07^{\mathrm{b}}$ & $0.97 \pm 0.11^{\mathrm{a}}$ & $1.31 \pm 0.11^{\mathrm{c}}$ \\
\hline Tryptophan & $0.21 \pm 0.02^{\mathrm{a}}$ & $0.20 \pm 0.01^{\mathrm{a}}$ & $0.30 \pm 0.05^{\mathrm{b}}$ \\
\hline Valine & $1.41 \pm 0.08^{\mathrm{b}}$ & $1.25 \pm 0.11^{\mathrm{a}}$ & $1.58 \pm 0.12^{\mathrm{c}}$ \\
\hline Total & $9.91 \pm 0.47^{\mathrm{ab}}$ & $9.38 \pm 0.71^{\mathrm{a}}$ & $10.40 \pm 0.73^{\mathrm{b}}$ \\
\hline Total amino acids $(\%)$ & $45.3 \pm 0.8^{\mathrm{b}}$ & $47.0 \pm 1.2^{\mathrm{c}}$ & $43.0 \pm 0.9^{\mathrm{a}}$ \\
\hline \multicolumn{4}{|c|}{ Non-essential amino acids } \\
\hline Alanine & $1.79 \pm 0.13^{\mathrm{b}}$ & $1.44 \pm 0.18^{\mathrm{a}}$ & $2.14 \pm 0.20^{c}$ \\
\hline Aspartic acid & $2.77 \pm 0.25^{\mathrm{b}}$ & $2.29 \pm 0.28^{\mathrm{a}}$ & $3.49 \pm 0.31^{\mathrm{c}}$ \\
\hline Cysteine & $0.50 \pm 0.09^{\mathrm{ab}}$ & $0.59 \pm 0.10^{\mathrm{b}}$ & $0.48 \pm 0.05^{\mathrm{a}}$ \\
\hline Glutamic acid & $2.52 \pm 0.27$ & $2.71 \pm 0.24$ & $2.75 \pm 0.22$ \\
\hline Glycine & $1.47 \pm 0.10^{\mathrm{b}}$ & $1.11 \pm 0.15^{\mathrm{a}}$ & $1.79 \pm 0.16^{\mathrm{c}}$ \\
\hline Lanthanide & $0.00 \pm 0.00$ & $0.00 \pm 0.00$ & $0.00 \pm 0.00$ \\
\hline Proline & $1.08 \pm 0.07$ & $0.96 \pm 0.18$ & $1.06 \pm 0.15$ \\
\hline Serine & $1.09 \pm 0.07^{\mathrm{b}}$ & $0.87 \pm 0.10^{\mathrm{a}}$ & $1.13 \pm 0.11^{\mathrm{b}}$ \\
\hline Tyrosine & $0.76 \pm 0.04^{\mathrm{a}}$ & $0.65 \pm 0.09^{\mathrm{a}}$ & $0.98 \pm 0.15^{\mathrm{b}}$ \\
\hline Total & $11.97 \pm 0.81$ & $10.62 \pm 1.20$ & $13.83 \pm 1.27$ \\
\hline Total amino acids (\%) & $54.7 \pm 0.8$ & $53.0 \pm 1.20$ & $57.0 \pm 0.9$ \\
\hline \multicolumn{4}{|l|}{ Sulfonic acids } \\
\hline Taurine & $0.10 \pm 0.02^{\mathrm{a}}$ & $0.82 \pm 0.27^{\mathrm{b}}$ & $0.12 \pm 0.05^{\mathrm{a}}$ \\
\hline Total amino acids & $21.89 \pm 1.25^{\mathrm{a}}$ & $20.00 \pm 1.88^{\mathrm{a}}$ & $24.22 \pm 1.96^{\mathrm{b}}$ \\
\hline
\end{tabular}

Table 5. Protein / nitrogen ratio for Pacific dulse, Turkish towel, and sea lettuce

\begin{tabular}{ll}
\hline Species & P / N ratio \\
\hline Pacific dulse & $4.66 \pm 0.11^{\mathrm{a}}$ \\
Turkish towel & $4.47 \pm 0.12^{\mathrm{b}}$ \\
Sea lettuce & $4.51 \pm 0.15^{\mathrm{ab}}$ \\
\hline
\end{tabular}

Values are presented as mean \pm standard deviation $(n=8)$. Values in the same row with different letters are significantly different $(p<0.05$, Tukey honest significant difference).

$\begin{array}{llllll}\text { Turkish towel } & 0.69 \pm 0.4 & 1.42 \pm 0.9 & 1.01 \pm 0.3 & 0.71 \pm 0.4 & \text { Tukey honest significant difference). }\end{array}$

Ash

$\begin{array}{lllll}\text { Pacific dulse } & 39.9 \pm 4.4 & 42.1 \pm 1.6 & 43.0 \pm 0.7 & 43.7 \pm 1.0\end{array}$

$\begin{array}{lllll}\text { Turkish towel } & 35.4 \pm 1.3 & 36.2 \pm 3.4 & 36.0 \pm 0.8 & 36.6 \pm 0.4\end{array}$

$\begin{array}{lllll}\text { Sea lettuce } & 35.7 \pm 3.4 & 37.8 \pm 6.7 & 31.8 \pm 1.5 & 31.2 \pm 1.0\end{array}$

Dry weight

$\begin{array}{lllll}\text { Pacific dulse } & 8.8 \pm 0.7 & 9.6 \pm 0.9 & 10.2 \pm 0.2 & 9.7 \pm 0.2\end{array}$

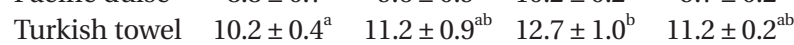
$\begin{array}{lllll}\text { Sea lettuce } & 14.4 \pm 1.8 & 14.7 \pm 1.8 & 13.4 \pm 0.4 & 13.4 \pm 0.3\end{array}$

Values are presented as mean \pm standard deviation $(n=6)$. Values in the same row with different letters are significantly different $(p<0.05$, Tukey honest significant difference).
Table 6. Mean content for arsenic, cadmium, and lead of macroalgae ( $\mathrm{mg} \mathrm{kg}^{-1}$ dry weight)

\begin{tabular}{lccc}
\hline \multicolumn{1}{c}{ Metal } & Pacific dulse & Turkish towel & Ulva \\
\hline Arsenic $(\mathrm{As})$ & $5.48 \pm 1.69^{\mathrm{a}}$ & $10.95 \pm 1.95^{\mathrm{b}}$ & $5.78 \pm 1.47^{\mathrm{a}}$ \\
Cadmium $(\mathrm{Cd})$ & $1.28 \pm 0.57$ & $1.68 \pm 0.25$ & $1.18 \pm 0.10$ \\
Lead $(\mathrm{Pb})$ & $<1$ & $<1$ & $<1$ \\
\hline
\end{tabular}

Values are presented as mean \pm standard deviation $(n=4)$. Values in the same row with different letters are significantly different $(p<0.05$, Tukey honest significant difference). 
Table 7. Contaminant levels in macroalgae ( $\mathrm{ng} \mathrm{g}^{-1}$ on wet weight basis)

\begin{tabular}{|c|c|c|c|c|c|}
\hline \multirow{2}{*}{ Species } & \multicolumn{5}{|c|}{ Parameter } \\
\hline & SHLDs $^{\mathrm{S}}$ & $\operatorname{Sum}_{\text {DDTs }^{b}}$ & $\underset{\mathrm{HCHs}^{\mathrm{c}}}{\mathrm{Sum}}$ & $\operatorname{Sum}_{40 P C s^{d}}$ & $\operatorname{Sum}_{\text {BDE }^{e}}$ \\
\hline \multirow[t]{4}{*}{ Pacific dulse } & $<$ LOQ & $<\mathrm{LOQ}$ & $<\mathrm{LOQ}$ & 1.10 & $<\mathrm{LOQ}$ \\
\hline & $<$ LOQ & $<\mathrm{LOQ}$ & $<\mathrm{LOQ}$ & 1.10 & $<\mathrm{LOQ}$ \\
\hline & $<$ LOQ & $<\mathrm{LOQ}$ & $<\mathrm{LOQ}$ & 0.88 & $<\mathrm{LOQ}$ \\
\hline & $<$ LOQ & $<\mathrm{LOQ}$ & $<\mathrm{LOQ}$ & 1.00 & 0.083 \\
\hline \multirow[t]{4}{*}{ Turkish towel } & $<$ LOQ & $<\mathrm{LOQ}$ & $<\mathrm{LOQ}$ & 0.96 & $<$ LOQ \\
\hline & $<\mathrm{LOQ}$ & $<\mathrm{LOQ}$ & $<\mathrm{LOQ}$ & 0.77 & 0.22 \\
\hline & $<\mathrm{LOQ}$ & $<\mathrm{LOQ}$ & $<\mathrm{LOQ}$ & 0.87 & 0.16 \\
\hline & $<$ LOQ & $<\mathrm{LOQ}$ & $<\mathrm{LOQ}$ & 1.80 & $<$ LOQ \\
\hline \multirow[t]{4}{*}{ Sea lettuce } & $<\mathrm{LOQ}$ & $<\mathrm{LOQ}$ & $<\mathrm{LOQ}$ & 1.20 & $<\mathrm{LOQ}$ \\
\hline & $<$ LOQ & $<\mathrm{LOQ}$ & $<\mathrm{LOQ}$ & 1.50 & $<\mathrm{LOQ}$ \\
\hline & $<\mathrm{LOQ}$ & $<\mathrm{LOQ}$ & $<\mathrm{LOQ}$ & 0.83 & 0.092 \\
\hline & $<\mathrm{LOQ}$ & $<\mathrm{LOQ}$ & 0.09 & 1.80 & $<\mathrm{LOQ}$ \\
\hline
\end{tabular}

The data were collected on Aug 30 and Dec 2, 2013 and Feb 28 and Jun 2, 2014.

LOQ, limit of quantification.

${ }^{\text {a }}$ Sum chlordanes (CHLDs) is the sum of a-chlordane, cis-nonachlor, g-chlordane, heptachlor, heptachlor epoxide, nonachlor III, oxychlordane, and trans-nonachlor.

${ }^{b}$ Sum DDTs is the sum of opDDD, opDDE, opDDT, ppDDD, ppDDE, and ppDDT.

'Sum hexachlorocyclohexanes $(\mathrm{HCHs})$ is the sum of $\mathrm{aHCH}, \mathrm{bHCH}$, and lindane $(\mathrm{gHCH})$.

${ }^{d}$ Sum $40 P C B s$ is the sum of 40 chlorobiphenyl congeners (plus their coelutors).

${ }^{\text {e}} \mathrm{Sum} \mathrm{BDEs}$ is the sum of all the individual BDE congeners.

\section{Persistent organic pollutants}

The concentrations of POPs are presented in Table 7 in terms of $\mathrm{ng} \mathrm{g}^{-1}$ wet weight. The Sum CHLDs, Sum DDTs, Sum HCHs, and Sum BDEs were close to the level of detection (or limit of quantification) and there were only 17 valid values out of 60 analytes.

\section{Taxonomic identification}

We managed to amplify tufA from 15 specimens morphologically assignable to the genus Ulva. Of these, three were $100 \%$ matched to Ulva lobata (Kützing) Harvey (although one had trace signal for Ulva stenophylla Setchell \& Gardner suggesting a mixture of specimens in the sample) and 12 were $100 \%$ matched to U. stenophylla (Table 8). For the rhodophycean specimen morphologically assigned to Chondracanthus the COI-5P data were a 100\% match to C. exasperatus (Table 8). Specimens morphologically assigned to the rhodophycean genus Palmaria were resolved with COI-5P $(\mathrm{n}=2)$ and $r b c \mathrm{~L}-3 \mathrm{P}(\mathrm{n}=2)$ as $100 \%$ matched to P. mollis (Table 8).

Both sea lettuce tanks were stocked from the same source and contained both $U$. lobata and $U$. stenophylla

Table 8. Specimens assessed by molecular identification with the GenBank accession numbers for the appropriate markers included

\begin{tabular}{|c|c|c|c|c|c|c|c|}
\hline Genetic group & Tank No. & Date & BOLD & Voucher & tuf $\mathrm{A}^{\mathrm{a}}$ & COI-5P & $r b c \mathrm{~L}-3 \mathrm{P}$ \\
\hline \multirow[t]{2}{*}{ Ulva lobata } & 2 & Aug 1, 2013 & ULVA1754-15 & GWS040565 & KX281918 & - & - \\
\hline & 2 & Sep 1, 2013 & ULVA1758-15 & GWS040569 & KX281909 & - & - \\
\hline \multirow[t]{12}{*}{ Ulva stenophylla } & 2 & Nov 1, 2013 & ULVA1760-15 & GWS040571 & KX281905 & - & - \\
\hline & 2 & Jan 31, 2014 & ULVA1762-15 & GWS040573 & KX281906 & - & - \\
\hline & 2 & Feb 28, 2014 & ULVA1723-15 & GWS039581 & KX281903 & - & - \\
\hline & 2 & Apr 30, 2014 & ULVA1764-15 & GWS040575 & KX281908 & - & - \\
\hline & 4 & Aug 1, 2013 & ULVA1755-15 & GWS040566 & KX281916 & - & - \\
\hline & 4 & Aug 30, 2013 & ULVA1721-15 & GWS039579 & KX281913 & - & - \\
\hline & 4 & Aug 30, 2013 & ULVA1757-15 & GWS040568 & KX281914 & - & - \\
\hline & 4 & Sep 1, 2013 & ULVA1759-15 & GWS040570 & KX281902 & - & - \\
\hline & 4 & Nov 1, 2013 & ULVA1761-15 & GWS040572 & KX281915 & - & - \\
\hline & 4 & Dec 2, 2013 & ULVA1722-15 & GWS039580 & KX281912 & - & - \\
\hline & 4 & Jan 31, 2014 & ULVA1763-15 & GWS040574 & KX281917 & - & - \\
\hline & 4 & Apr 30, 2014 & ULVA1765-15 & GWS040576 & KX281910 & - & - \\
\hline Ulva lobata ${ }^{\mathrm{b}}$ & 4 & Jun 12, 2014 & ULVA1724-15 & GWS039582 & KX281911 & - & - \\
\hline $\begin{array}{l}\text { Chondracanthus } \\
\text { exasperatus }\end{array}$ & 1 & Aug 1, 2013 & ABMMC21001-15 & GWS036289 & - & KX281899 & - \\
\hline \multirow[t]{4}{*}{ Palmaria mollis } & 3 & Aug 1, 2013 & ABMMC20989-15 & GWS036291 & - & - & KX281901 \\
\hline & 3 & Aug 1, 2014 & ABMMC20991-15 & GWS036297 & - & KX281897 & - \\
\hline & 6 & Aug 1, 2013 & ABMMC20990-15 & GWS036294 & - & KX281898 & - \\
\hline & 6 & Aug 1, 2014 & ABMMC20992-15 & GWS039508 & - & - & KX281900 \\
\hline
\end{tabular}

a Ulva spp. taxonomy is in considerable need of taxonomic investigation. These were a $100 \%$ match to data associated with these specific epithets, and thus represent the same genetic groups, as reported in Saunders and Kucera (2010).

${ }^{\mathrm{b}}$ Trace sequence of Ulva stenophylla was present in this polymerase chain reaction (PCR) product suggesting that both species were present in the material used to isolate DNA for this specimen. PCR contamination is an alternative explanation. 
at some point in time (Table 8). At the start of the experiment, Tank 2 contained $U$. lobata but this changed to $U$. stenophylla by the start of the third month and continued to the end of the experiment. Tank 4 contained U. stenophylla for the entire experiment, but trace amounts of $U$. lobata were present at the last sample.

\section{DISCUSSION}

\section{Growth rates}

Based on an initial biomass of $4.11 \mathrm{~kg} \mathrm{~m}^{-2}$, a bimonthly weighing, and exponential growth model, the mean annual growth rates varied from $2.7 \% \mathrm{~d}^{-1}$ for sea lettuce to $5.0 \% \mathrm{~d}^{-1}$ for Pacific dulse (Fig. 1) and was a significant function of day length (Fig. 2). Under natural seasonal lighting levels, the growth rate is a function of the specific light density (SLD, mole photons $\mathrm{g}^{-1} \mathrm{~d}^{-1}$ ) (Demetropoulos and Langdon 2004a):

$$
\operatorname{SLD}\left(\text { mol photon } \mathrm{g}^{-1} \mathrm{~d}^{-1}\right)=\frac{\text { PFD } \times \mathrm{SA}}{\text { Biomass }}
$$

, where PFD is photon-flux density (mol photons $\mathrm{m}^{-2} \mathrm{~d}^{-1}$ ), $\mathrm{SA}$ is surface area of illuminated surface $\left(\mathrm{m}^{2}\right)$, Biomass is biomass of macroalgae in tank (g).

The SGR of Pacific dulse were highly correlated with SLD over a range of 0.0048 to 0.036 mol photon $\mathrm{g}^{-1}$ wet weight $\mathrm{d}^{-1}$ (Demetropoulos and Langdon 2004a). At very high values of PFD, the SGR of Ulva rigida can be as high as $20 \% \mathrm{~d}^{-1}$ (Rautenberger et al. 2015). In contrast, the highest value of SGR for sea lettuce in our work was only $6.2 \% \mathrm{~d}^{-1}$. The reduced growth rate for sea lettuce in our work is a result of much lower SLD and longer growth periods. Therefore, if the initial density is held constant, the growth rate will vary with the seasonal variation in PFD and with day length. For production conditions, a seasonal density criteria may be desirable.

The observed seasonal variation in our growth rates were best correlated with day length (Fig. 2) followed by temperature (Table 1) and salinity. There was a better correlation between temperature and day length than between temperature and SGR. Clear separation of the impact of temperature and salinity on growth rate cannot be done with this data because both temperature and salinity are simultaneously changing over the year.

Some of the best research on the impacts of temperature and salinity has been conducted on Pacific dulse (Demetropoulos and Langdon 2004a). They found that lowering salinity from 35 to 30 psu resulted in SGRs that were 8.8 to $14.3 \%$ higher and that the optimal temperature for growth was $12^{\circ} \mathrm{C}$ for low light conditions and 14$18^{\circ} \mathrm{C}$ for high light conditions. The salinity at Sinclair Inlet near the Manchester Field Station is $29 \pm 1$ psu which indicates that this site is a good match for Pacific dulse culture. The maximum average daily temperature at the Manchester Field Station approached $18^{\circ} \mathrm{C}$ (Table 1). Based on average daily temperatures, the impact of temperature appears to be small for Pacific dulse; the potential impact of maximum daily temperatures is unknown at this time. Pacific dulse is found in the lower littoral zone; followed by Turkish towel and sea lettuce as one moves towards the upper littoral zone. Based on this distribution, it can be hypothesized that both Turkish towel and sea lettuce are less sensitive to temperature changes. In commercial tumble culture, engineering options are available to adjust temperature over a significant range (Davison and Piedrahita 2015).

In the tumble culture system used in this work, the growth rate depends on the species, surface irradiance, tank depth and width, and circulation time (Pang and Lüning 2004). As the macroalgae rotates in the tanks, it is exposed to surface light levels for a short time and then plunges into the dark as it descends to the bottom of the tank. In Atlantic dulse (Palmaria palmata (Linnaeus) F. Weber \& D. Mohr), the growth rate increased up to an irradiance of $1,600 \mu \mathrm{mol} \mathrm{m}^{-2} \mathrm{~s}^{-1}$ and no signs of chronic photoinhibition were observed (Pang and Lüning 2004). It was hypothesized that the dark interval prevented chronic photoinhibition of photosynthesis. The relationship between tank geometry (width and depth), rotational speed, density, and light levels on the growth of macroalgal species is not well understood. The culture systems used for macroalgae have developed empirically without a clear understanding of the relationship between these variables.

The growth of macroalgae is commonly assumed to be an exponential function and the growth rate reported as SGR (Eq. 1). Implicit with this model is that:

$$
\begin{gathered}
\frac{\mathrm{dW}}{\mathrm{dt}} \propto \mathrm{W} \\
\mathrm{W}_{\mathrm{f}}=\mathrm{W}_{\mathrm{i}} \operatorname{Exp}\left(\frac{\mathrm{SGR}}{100} \times \mathrm{t}\right)
\end{gathered}
$$

, where dW is change in weight (g), dt is change in time $(\mathrm{s}), \mathrm{W}_{\mathrm{f}}$ is final weight (g), $\mathrm{W}_{\mathrm{i}}$ is initial weight (g), SGR is specific growth rate $\left(\% \mathrm{~d}^{-1}\right)$, and $t$ is time $(\mathrm{d})$. 
The determination of the SGR can be based on nonlinear regression of $\mathrm{W}$ with time or a linear regression of $\ln (\mathrm{W})$ with time. More commonly, the SGR is computed from the initial weight, final weight and harvest interval using Eq. (1). Based on a seven-day growth experiment, Yong et al. (2013) found that the SGR did not give the best fit to experimental macroalgal growth data.

Demetropoulos and Langdon (2004a), found that the SGR was a strong function of aerial density:

$$
\operatorname{SGR}\left(\% \mathrm{~d}^{-1}\right)=20.517 \operatorname{Exp}(-0.25847 \mathrm{AD})
$$

, where AD is aerial density $\left(\mathrm{kg}\right.$ wet weight $\left.\mathrm{m}^{-2}\right)$.

In our work, it was not unusual for the final weights to be 2-3 times the initial weights during high light conditions. Therefore, the instantaneous SGR at the end of period may be only $1 / 7$ of the value at the start (Eq. 6)

As a result, the SGR computed from Eq. (5) will depend strongly on the initial density and harvest interval and represent an average growth rate over the interval. The development of a harvest model with a strong densitydependent relationship or the ability to measure instantaneous growth rates are needed.

The measured growth rates in this study compare favorably with reported valves for similar densities and harvest intervals (Table 9), but less than reported for lower densities and shorter harvest intervals. This table tried to focus on studies that determined the SGR over the year and with defined initial stocking densities and harvest intervals; not all studies listed in this table meet all these criteria.

\section{Yield}

While many researchers describe their work in terms of growth rate, yield is much more relevant for production work. For Pacific dulse, Demetropoulos and Langdon (2004a) found that the highest yields occurred for an initial density between 3.5 to $4.0 \mathrm{~kg}$ wet weight $\mathrm{m}^{-2}$. The yields were lower for both densities higher and lower than this value. This information was the basis for the selection of the initial density used in this research. Due to differences in photosynthetic efficiency, the optimum initial densities for Turkish towel and sea lettuce could be quite different. In addition, the initial density should also depend on ambient light levels (Eq. 3) and harvest intervals. Direct measurements of light levels within tumble culture systems may offer an effective way to develop protocols for stocking and harvest.

Yields and SGRs are interrelated by Eq. (7)

$$
\mathrm{SGR}=\ln \left[\frac{\text { Yield } \times \mathrm{t} \times \mathrm{SA}}{\mathrm{W}_{\mathrm{i}}}+1\right] / \mathrm{t}
$$

Eq. (7) can be developed by substituting the relationship for final weight for the SGR equation (Eq. 5) into the Yield equation (Eq. 2). For positive values of Yield, there is a linear relationship between Yield and SGR. For small negative yields, the relationship becomes non-linear and is not defined for Yield $\times \mathrm{SA}+1<1$. The relationship between yield and growth rate will depend on the growth model selected. While the SGR may fit macroalgae growth at low densities and high SLD, it is less likely to be valid at high densities and low SLDs. More research is needed to be able to accurately model macroalgae in commercial tumble culture applications.

\begin{tabular}{|c|c|c|c|c|c|}
\hline \multirow{2}{*}{ Species } & \multirow{2}{*}{ Harvest interval } & \multicolumn{2}{|c|}{ SGR $\left(\% \mathrm{~d}^{-1}\right)$} & \multirow{2}{*}{ Fertilization } & \multirow{2}{*}{ Source } \\
\hline & & Mean annual & Range & & \\
\hline \multirow[t]{2}{*}{ Pacific dulse } & 2 months & 5.0 & 1.5 to 8.2 & Yes & This study \\
\hline & 7 days & - & 3.6 to 16.5 & Yes & Demetropoulos and Langdon (2004b) \\
\hline \multirow[t]{2}{*}{ Palmaria palmata } & Biweekly & - & -1 to 1.1 & IMTA & Corey et al. (2014) \\
\hline & 3 days & - & 3 to 17 & Yes & Pang and Lüning (2004) \\
\hline Chondrus cripus & NA & - & 0 to 9 & Yes & Craigie and Shacklock (1995) \\
\hline \multirow[t]{2}{*}{ Turkish towel } & 2 months & 4.3 & 1.5 to 7.6 & Yes & This study \\
\hline & NA & - & 4 to 5 & Yes & Waaland (2004) \\
\hline Sea lettuce & 2 months & 2.7 & -5.0 to 6.2 & Yes & This study \\
\hline \multirow[t]{2}{*}{ Ulva lactuca } & 7 days & - & 0 to 22 & Yes & Fortes and Lüning (1980) \\
\hline & 14 days & - & 11.4 to 19.3 & Yes & Neori et al. (1998) \\
\hline
\end{tabular}

Table 9. Specific growth rates (SGR) of cultured macroalgae

A "Yes" for fertilization means use of inorganic $\mathrm{N}$ and $\mathrm{P}$ fertilizers; integrated multi-trophic aquaculture (IMTA) uses discharge from fish culture to provide $\mathrm{N}$ and $\mathrm{P}$.

NA, not available. 


\section{Overall product quality}

In terms of macroinvertebrates, the macroalgae reared in this study were free of the typical fouling organisms common to wild collected macroalgae. The lack of these organisms was partially due to the filtration and disinfection of the process water prior to its use with the finfish. In addition, the draining and cleaning of the tanks on a bimonthly basis eliminated most organisms that made it through the influent treatment system. The lack of the common herbivorous invertebrates will reduce processing expenses and increase growth rates of the macroalgae due to reduced grazing (Robertson-Andersson et al. 2008).

The amount of contamination by other macroalgae was highly variable and ranged to 0 to $9 \%$ on a wet weight basis. The type and level of contamination depended on species and was not consistent between replicates. Most of these green macroalgal contaminants were not epiphytes as they were not attached to the primary cultured species. Control of macroalgal contaminants is a topic that will be important to commercialization of landbased culture systems.

Based on molecular markers, two Ulva species were present in this study: U. lobata and U. stenophylla (Table 8). These two species are not even listed in common field guides for Pacific Northwest macroalgae, however, Ulva taxonomy is in a state of flux and the specific epithets to be assigned to these genetic groups has yet to be finalized (Saunders and Kucera 2010). In fact, it is argued that many published references to Ulva species may be in error (Bolton et al. 2009). Analysis showed that initially, each species was present in one tank. U. stenophylla replaced $U$. lobata within 2-3 months in Tank 2. Tank 4 was consistently $U$. stenophylla, except for potentially the last observation. In mixed culture of Ulva spp., dominance can change rapidly and appears related to ambient light levels and shading (Bolton et al. 2009).

\section{Proximate composition}

Very little information is available on the seasonal variation of land-based macroalgae; most information is available for wild harvest or in-water rearing systems. The degree to which inputs, environmental parameters, and duration of sampling time are controlled in intensive culture may have a significant impact on proximate values compared to wild-harvested macroalgae.

Results from this study showed no statistically significant seasonal impact on proximate constituents for any of the three macroalgal species in the study (Table 3), although significant differences were observed for overall compositions between macroalgae over the 1-year period (Fig. 4). The absence of significant seasonal change may be due to more control in land-based rearing practices such as regular fertilization, fixed harvest intervals, and better density control. Seasonal compositional variation in wild populations may be due to environmental changes (light, salinity, and temperature), variation in the nutrient concentrations, and seasonal development cycles. The three species in this study were vegetatively reared and as a result proximate compositions may be more stable than plants with annual development cycles.

The protein content of Pacific dulse averaged 25\% on a dry weight basis in this study. This is slightly higher than previously reported for wild Atlantic dulse that spanned from $12 \%$ in summer-autumn to $22 \%$ in winter-spring (Galland-Irmouli et al. 1999), but similar to that reported for some tank culture (Morgan et al. 1980). The protein content of Turkish towel similarly averaged $24 \%$ in this study and was significantly higher than previously reported for this genus in the wild (McCusker et al. 2014). The protein content of sea lettuce averaged $29 \%$ in this study, which is similar to that reported by McCusker et al. (2014), but higher than that reported by other researchers as summarized by Fleurence (1999). The highest values of protein were observed during winter months for Atlantic dulse and sea lettuce, but were not significantly different between seasons.

The total crude lipid contents in the three seaweeds were low throughout the study with no significant seasonal differences. Lipid content was comparable to values previously reported for Atlantic dulse (Morgan et al. 1980) and other edible red and green macroalgae (Fleurence et al. 1994). Sea lettuce had the highest overall lipid content with the highest values during spring (3.19\%) and summer (3.67\%) as observed in other studies with Ulva species (Renaud and Luong-Van 2006, Khairy and El-Shafay 2013). In contrast, other red and green macroalgal species are reported to have higher lipid levels in winter (rainy seasons) and summer seasons (Nelson et al. 2002, Benjama and Masniyom 2011). Differences in lipid content may be due to rearing conditions and environmental factors.

Ash contents determined in both red and green macroalgae over the 1-year study did not indicate any seasonal differences and were similar or higher to those previously reported in the literature (Benjama and Masniyom 2011, Khairy and El-Shafay 2013, Polat and Ozogul 2013). Ash content in Pacific dulse (43.7\%) was signifi- 
cantly higher than the other two macroalgae cultured in this land-based system. In comparison, Atlantic dulse has been reported to have a wide range of ash weights (11.7-36\%) in literature compiled by Morgan et al. (1980).

In summary, the study found no significant trend in proximate composition of protein, lipid, or ash content with season. This may be attributed to a more controlled environment in a land-based culture system where nutrient inputs and environmental parameters (temperature, density, and salinity) are less variable than in a wild harvesting area. Throughout the 1-year study, sea lettuce was significantly higher in protein and lipid while higher ash content was observed in Pacific dulse.

\section{Protein / nitrogen ratio}

The 6.25 factor used to convert nitrogen content to protein dates back to the 19th century and is based on the assumption that the nitrogen content of protein is $16 \%$ (Mariotti et al. 2008). In macroalgae, "the presence of non-protein substances in high concentrations, such as pigments (chlorophyll and phycoerythrin) and inorganic nitrogen (nitrate, nitrite, and ammonia), gives an overestimation of the actual protein content by use of the factor 6.25" (Lourenço et al. 1998).

Limited information is available for specific proteinnitrogen conversion factors for macroalgae (Table 10). The protein / nitrogen ratio for terrestrial cereals and grains is $5.50 \pm 0.14$ and the average default factor for all foods is 5.6 (Mariotti et al. 2008). For most trade and food regulations, the official factor is 6.25 (Mariotti et al. 2008).

Because the majority of published macroalgal protein values are based on the 6.25 factor, all protein values in this work are based on the historical factor of 6.25. Using the combined factor (4.55) determined in this study, the crude protein $(\mathrm{N} \times 6.25)$ is $27.2 \%$ higher than the "actual protein" content computed from Food and Agriculture Organization of the United Nations (2003). The "actual protein" is equal to $0.792 \times$ crude protein reported in this study.

\section{Amino acids}

The total amino acid profile (Table 4), for all three macroalgal species cultivated was representative of amino acid profiles of green and red macroalgae in the current literature (Fleurence 1999, Lourenço et al. 2002, McCusker et al. 2014). Lysine and methionine, which are often limiting in terrestrial plant proteins, were well represented in all three species. Total essential amino acids (EAA) present accounted for $43-47 \%$ of total amino acids analyzed with the red macroalgal Turkish towel being significantly higher in total EAA $(47 \pm 1.2 \%, \mathrm{p}<0.05)$. Slightly lower percentages were reported for wild Ulva and Atlantic dulse (Galland-Irmouli et al. 1999, Lourenço et al. 2002). Expressed on a dry matter basis, EAA of sea lettuce and Pacific dulse were similar to that reported by McCusker et al. (2014), while both EAA and protein in Turkish towel was higher than that reported for this genus by these authors.

The two amino acids present in the highest concentration in all three macroalgal species were aspartic and glutamic acids (Table 4). Aspartic acid was significantly higher in sea lettuce than both red macroalgal species cultured $(p<0.05)$ but glutamic acid was not significantly different. These two non-essential amino acids often comprise a large portion of the total amino acids in macroalgae (Fleurence 1999, Lourenço et al. 2002). Aspartic and glutamic acids in the red and green macroalgal species in this study represented $24-25 \%$ of the total amino acids. This is similar, but slightly higher to ranges previously reported for brown macroalgae (15.8 to $20.2 \%$ ) and green macroalgae (15.2 to 21.9\%) (Fleurence et al. 1995), but within the ranges reported for red macroalgae (10.9 to $25.5 \%$ ) (Fleurence et al. 1995, Galland-Irmouli et al. 1999).

Taurine, a sulfonic acid, was present in low concentration in two of the macroalgal species sea lettuce $(0.12 \pm$ $0.05 \%)$ and Pacific dulse $(0.10 \pm 0.02 \%)$, but was elevated in Turkish towel $(0.82 \pm 0.27 \%)$. Similarly, McCusker et al. (2014) found taurine to be elevated in some wild red macroalgae, including the genus Chondracanthus (0.63

Table 10. Specific protein-nitrogen conversion factors for macroalgae

\begin{tabular}{ccccl}
\hline Red & Green & Brown & Combined & \multicolumn{1}{c}{ Source } \\
\hline $4.66 \pm 0.11$ & $4.51 \pm 0.15$ & - & $4.55 \pm 0.15$ & This study \\
$4.47 \pm 0.12$ & - & - & - & This study \\
5.00 & - & - & - & Aitken et al. (1991) \\
$4.59 \pm 0.54$ & $5.15 \pm 0.39$ & $5.38 \pm 0.50$ & $4.92 \pm 0.59$ & Lourenço et al. (2002) \\
\hline
\end{tabular}

Values are presented as mean \pm standard deviation $(n=8)$. 
g $100 \mathrm{~g} \mathrm{~g}^{-1} \mathrm{DW}$ ). The taurine content of Turkish towel was significantly higher than sea lettuce and Pacific dulse ( $\mathrm{p}$ $<0.05$, Tukey HSD). Taurine has been shown to be present in greater concentration in red macroalgae compared to brown and green macroalgae (Dawczynski et al. 2007, McCusker et al. 2014). As such, Turkish towel could be considered as a source of taurine in animal or human diets. In addition to other health benefits, taurine has been shown to be beneficial in human cardiovascular processes (Maehre et al. 2014).

\section{Persistent organic pollutants}

The levels of POPs in farmed macroalgae were very low. For CHLDs, DDTs, HCHs, and BDEs (Table 7), there were only 20 values (out of 75 samples) that were greater than the detection limits. PCBs were detected in all samples but were very low.

From a human health prospective, it is important to understand the relative concentration of PCBs in relationship to other seafood and their consumption rates. The ratio of POPs in fish: macroalgae in the Puget Sound area ranges from 4 for $\mathrm{HCH}, 59$ for DDT, and 69 for PCB (Williams and Krueger 1988). As a result, the potential health risks for the consumption of macroalgae is much less than for the consumption of an equal amount of fish or higher trophic level organisms.

\section{Heavy metals}

The cadmium and lead content of macroalgae (Table 6) are low and unlikely to be important to human health. The arsenic levels are of more concern as clinical arsenic poisoning from ingestion of kelp-based health supple-

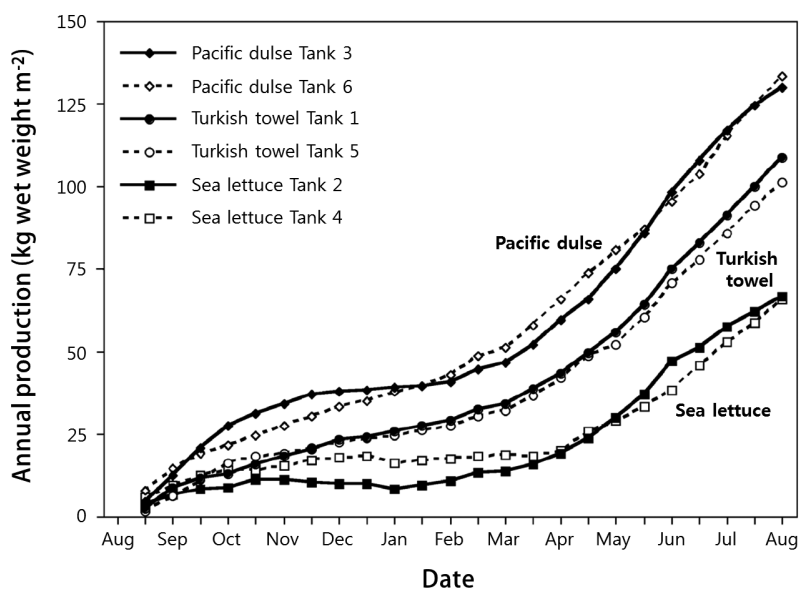

Fig. 5. Cumulative production $\left(\mathrm{kg}\right.$ wet weight $\mathrm{m}^{-2}$ ) from August 2013 to August 2014.

ments has occurred (Walkiw and Douglas 1975). Background concentrations of arsenic in seawater range from 2-5 $\mathrm{g} \mathrm{L} \mathrm{L}^{-1}$ (Chew 1996). Arsenic can be found in marine organisms as inorganic or organic compounds and it is generally assumed that the inorganic compounds are more toxic. Regulatory limits (Chew 1996, Smith et al. 2010) may be based on total arsenic (1-10 $\mathrm{mg} \mathrm{kg}^{-1}$ for Hong Kong, Malaysia, and Norway) or inorganic arsenic (1 mg kg ${ }^{-1}$ for Australia and New Zealand). The New Zealand standards are based on the dry weight values adjust to $85 \%$ moisture (Smith et al. 2010).

The total arsenic content of the farmed Turkish towel was significantly higher than the farmed Pacific dulse or sea lettuce. Smith et al. (2010) found a $27 \times$ time difference between different species and a 2-3x difference between sampling periods. They found the highest arsenic

Table 11. Estimated annual production of farmed macroalgae on a wet and dry weight basis

\begin{tabular}{|c|c|c|c|c|c|c|c|}
\hline \multirow{2}{*}{ Species } & \multirow{2}{*}{$\begin{array}{l}\text { Initial density } \\
\qquad\left(\mathrm{kg} \mathrm{m}^{-2}\right)\end{array}$} & \multicolumn{2}{|c|}{$\begin{array}{c}\text { Production } \\
\left(\mathrm{kg} \mathrm{m}^{-2} \mathrm{y}^{-1}\right)\end{array}$} & \multirow{2}{*}{$\begin{array}{l}\text { Production } \\
\text { (Max / Min) }\end{array}$} & \multicolumn{2}{|c|}{$\begin{array}{l}\text { Production } \\
\left(\text { tonne ha }^{-1} y^{-1}\right)^{a}\end{array}$} & \multirow{2}{*}{ Reference } \\
\hline & & WW & DW & & WW & DW & \\
\hline $\begin{array}{l}\text { Gracilaria } \\
\quad \text { vermiculophylla }\end{array}$ & 3 & 51 & 8.7 & 3.6 & 255 & 43 & Abreu et al. (2011) \\
\hline \multirow[t]{2}{*}{ Palmaria plamata } & $3-10$ & $28-34^{\mathrm{b}}$ & $6.9-8.6$ & $4.4-4.8^{\mathrm{c}}$ & $140-172$ & $35-43$ & Corey et al. (2014) \\
\hline & 4 & 48 & $12^{\mathrm{cd}}$ & $14-43$ & 240 & 60 & Werner and Dring (2011) \\
\hline Pacific dulse & 4.1 & 132 & 13 & 7.2 & 660 & 64 & This study \\
\hline Turkish towel & 4.1 & 105 & 12 & 7.4 & 525 & 59 & This study \\
\hline Ulva lactuca & 1.5 & 84 & 15 & $2.6-7.7$ & 420 & 77 & Neori et al. (1998) \\
\hline Sea lettuce & 4.11 & 66 & 9 & 23 & 330 & 46 & This study \\
\hline
\end{tabular}

${ }^{\mathrm{a}}$ Based on a $50 \%$ tank coverage.

${ }^{\mathrm{b}}$ Based on a $25 \%$ dry weight (Jang Kim personal communications).

'Based on carbon removal, Systems 1 and 2.

${ }^{\mathrm{d}}$ Table 9.2, QUB Protaferry; T1 and T2. 
content in brown macroalgae $\left(97 \mathrm{mg} \mathrm{kg}^{-1}\right)$ and the lowest in green macroalgae $\left(0.14 \mathrm{mg} \mathrm{kg}^{-1}\right)$.

Limited information is available on the percent inorganic arsenic in Puget Sound macroalgae. Williams and Krueger (1988) assumed a value of $1 \%$ without justification. Chew (1996) suggested that a value of $10 \%$ could be used for a worst-case evaluation, but recommended that more analysis is needed. For both $1 \%$ and $10 \%$ inorganic arsenic content, all of the macroalgal samples would meet a $1 \mathrm{mg} \mathrm{kg}^{-1}$ inorganic arsenic criterion (adjusted to $85 \%$ moisture). This criterion is not protective for the consumption of large amounts of dry brown macroalgae for food or health food products.

\section{Production estimates}

The annual wet weight production values for Pacific dulse, Turkish towel, and sea lettuce were 132, 105, and $84 \mathrm{~kg} \mathrm{~m}^{-2} \mathrm{y}^{1}$, respectively (Fig. 5) and are the highest production values found in the macroalgal literature (Table 11). This may be due to controlled density, adequate fertilization, and acceptable temperatures. Most of the IMTA studies depended on fish to provide ammonia and phosphates and therefore may be nutrient limited for some portion of the year. The production values for Ulva lactuca (Neori et al. 1998) exceeded those found in this work. While this was an integrated seaweed, abalone, and fish system, the macroalgae were supplemented with inorganic fertilizers. In addition, the more constant temperatures and light levels in Israel are likely to be more conducive to the growth of sea lettuce than the cold and cloudy winters in the Pacific Northwest.

Based on the assumption of $50 \%$ tank coverage, the annual production of the three species reared in this study range from 330 to 660 tonne wet weight ha- $\mathrm{y}^{-1} \mathrm{y}^{1}$ and 46 to 64 tonne dry weight ha- $\mathrm{y}^{-1}$ (Table 11). These dry weight values are higher than conventional agricultural crops (United States Department of Agriculture 2016): wheat, 2.93; corn, 10.57; soybean, 3.23; and rice, 8.37 tonne ha-1 $\mathrm{y}^{1}$.

Commercial wild harvest of macroalgae in the Pacific Northwest is restricted because of potential impacts on carbon cycle, habitat, and substrate for invertebrates and fish. Large-scale development of in-water macroalgal farming may be subjected to regulatory delays from upland property owners, recreational boating, and fishing interests. Because of the ability to produce high-quality product (low POPs, low metals, and no mussel, barnacle, or snails) of consistent nutrient composition over the entire year, land-based systems may offer the greatest po- tential for increased macroalgal production in the Pacific Northwest. In addition, increased macroalgal production can improve the well-being of coastal communities by offering direct permanent employment (Rebours et al. 2014).

\section{ADDENDUM}

The scientific name of Pacific dulse has recently changed. Palmaria mollis is now Devaleraea mollis. Its authority should now be Devaleraea mollis (Setchell \& N. L. Gardner) G. W. Saunders, C. Jackson \& E. D. Salomaki. http://www.algaebase.org/search/species/ detail/?species_id=pf60befe55288066d.

Saunders, G. W., Jackson, C. \& Salomaki, E. D. 2018. Phylogenetic analyses of transcriptome data resolve familial assignments for genera of the red-algal Acrochaetiales-Palmariales Complex (Nemaliophycidae). Mol. Phylogenet. Evol. 119:151-159.

\section{ACKNOWLEDGEMENTS}

The Office of Aquaculture and the Northwest Fisheries Science Center, National Oceanographic and Atmospheric Administration funded this work. The molecular research was supported by grants to Gary Saunders from the Natural Science and Engineering Research Council of Canada, the Canada Foundation for Innovation and the New Brunswick Innovation Foundation grants to GWS. We thank Tanya Moore for generating the sequence data used in this study.

\section{REFERENCES}

Abreu, M. H., Pereira, R., Yarish, C., Buschmann, A. H. \& Sousa-Pinto, I. 2011. IMTA with Gracilaria vermiculophylla: productivity and nutrient removal performance of the seaweed in a land-based pilot scale system. Aquaculture 312:77-87.

Abreu, M. H., Varela, D. A., Henríquez, L., Villarroel, A., Yarish, C., Sousa-Pinto, I. \& Buschmann, A. H. 2009. Traditional vs. integrated multi-trophic aquaculture of Gracilaria chilensis C. J. Bird, J. McLachlan and E. C. Oliveira: productivity and physiological performance. Aquaculture 293:211-220.

Aitken, K. A., Melton, L. D. \& Brown, M. T. 1991. Seasonal protein variation in the New Zealand seaweeds Porphyra 
columbina Mont. \& Porphyra subtumens J. Ag. (Rhodophyceae). Jpn. J. Phycol. 39:307-317.

AOAC International. 2005. Official methods of analysis of AOAC International. 18th ed. AOAC International, Gaithersburg, MD, $1298 \mathrm{pp}$.

Benjama, O. \& Masniyom, P. 2011. Nutritional composition and physiochemical properties of two green seaweeds (Ulva pertusa and U. intestinalis) from the Pattani Bay in Southern Thailand. Songklanakarin J. Sci. Technol. 33:575-583.

Bidwell, R. G. S., McLachlan, J. \& Lloyd, N. D. H. 1985. Tank cultivation of Irish moss, Chondrus crispus Stackh. Bot. Mar. 28:87-97.

Bolton, J. J., Robertson-Andersson, D. V., Shuuluka, D. \& Kandjengo, L. 2009. Growing Ulva (Chlorophyta) in integrated systems as a commercial crop for abalone feed in South Africa: a SWOT analysis. J. Appl. Phycol. 21:575583.

Buschmann, A. H., Mora, O. A., Gómez, P., Böttger, M., Buitano, S., Retamales, C., Vergara, P. A. \& Gutierrez, A. 1994. Gracilaria chilensis outdoor tank cultivation in Chile: use of land-based salmon culture effluents. Aquac. Eng. 13:283-300.

Chan, J. C. -C., Cheung, P. C. -K. \& Ang, P. O. 1997. Comparative studies on the effect of three drying methods on the nutritional composition of seaweed Sargassum hemiphyllum (Turn.) C. Ag. J. Agric. Food Chem. 45:30563059.

Chew, C. M. 1996. Toxicity and exposure concerns related to arsenic in seafoods: an arsenic literature review for risk assessments. U.S. Environmental Protection Agency, Region 10. EPA 910-R-96-019. ICF Kaiser, Seattle, WA, 70 pp.

Corey, P., Kim, J. K., Duston, J. \& Garbary, D. J. 2014. Growth and nutrient uptake by Palmaria palmata integrated with Atlantic halibut in a land-based aquaculture system. Algae 29:35-45.

Cornish, M. L. \& Garbary, D. J. 2010. Antioxidants from macroalgae: potential applications in human health and nutrition. Algae 25:155-171.

Craigie, J. S. \& Shacklock, P. F. 1995. Culture of Irish moss. In Bogen, A. D. (Ed.) Cold-water Aquaculture in Atlantic Canada. 2nd ed. Canadian Institute for Research on Regional Development, Moncton, pp. 365-390.

Davison, A. V. \& Piedrahita, R. H. 2015. Temperature modeling of a land-based aquaculture system for the production of Gracilaria pacifica: possible system modifications to conserve heat and extend the growing season. Aquac. Eng. 66:1-10.

Dawczynski, C., Schuert, R. \& Jahreis, G. 2007. Amino acid, fatty acid, and dietary fibre in edible seaweed products. Food Chem. 103:891-899.

Demetropoulos, C. L. \& Langdon, C. J. 2004a. Enhance production of Pacific dulse (Palmaria mollis) for co-culture with abalone in a land-based system: effects of stocking density, light, salinity, and temperature. Aquaculture 235:471-488.

Demetropoulos, C. L. \& Langdon, C. J. 2004b. Enhanced production of Pacific dulse (Palmaria mollis) for co-culture with abalone in a land-based system: nitrogen, phosphorus, and trace metal nutrition. Aquaculture 235:433455.

Department of Ecology, Marine Water Monitoring. 2017. Long-term marine water quality data. Available from: https://fortress.wa.gov/ecy/eap/marinewq/mwdataset.asp? staID=129. Accessed Dec 10, 2017.

Fleurence, J. 1999. Seaweed proteins: biochemical, nutritional aspects and potential uses. Trends Food Sci. Technol. 10:25-28.

Fleurence, J., Gutbier, G., Mabeau, S. \& Leray, C. 1994. Fatty acids from 11 marine macroalgae of the French Brittany coast. J. Appl. Phycol. 6:527-532.

Fleurence, J., Massiani, L., Guyader, O. \& Mabeau, S. 1995. Use of enzymatic cell wall degradation for improvement of protein extraction from Chondrus crispus, Gracilaria verrucosa and Palmaria palmata. J. Appl. Phycol. 7:393395.

Food and Agriculture Organization of the United Nations. 2003. Food energy: methods of analysis and conversion factors. Food and Nutrition Paper 77. Food and Agricultural Organization of the United Nations, Rome, 93 pp.

Food and Agriculture Organization of the United Nations. 2014. The state of world fisheries and aquaculture 2014. Food and Agriculture Organization of the United Nations, Rome, 88 pp.

Fortes, M. D. \& Lüning, K. 1980. Growth rates of North Sea macroalgae in relation to temperature, irradiance and photoperiod. Helgol. Meeresunters. 34:15-29.

Galland-Irmouli, A. V., Fleurence, J., Lamghari, R., Luçon, M., Rouxel, C., Barbaroux, O., Bronowicki, J. P., Villaume, C. \& Guéant, J. L. 1999. Nutritional value of proteins from edible seaweed Palmaria palmata (dulse). J. Nutr. Biochem. 10:353-359.

Guillard, R. R. L. \& Ryther, J. H. 1962. Studies on marine plankton diatoms: I. Cyclothella nana Huntedt and Detonula confercacae (Cleve) Gran. Can. J. Microbiol. 8:229-239.

Gupta, S., Cox, S. \& Abu-Ghannam, N. 2011. Effects of different drying temperatures on the moisture and phytochemical constituents of edible Irish brown seaweed. 
Food Sci. Technol. 44:1266-1272.

Huguenin, J. E. 1976. An examination of problems and potentials for future large-scale intensive seaweed culture systems. Aquaculture 9:313-342.

Khairy, H. M. \& El-Shafay, S. M. 2013. Seasonal variations in the biochemical composition of some common seaweed species from the coast of Abu Qir Bay, Alexandria, Egypt. Oceanologia 55:435-452.

Kim, J. K. \& Yarish, C. 2014. Development of a sustainable land-based Gracilaria cultivation system. Algae 29:217225 .

Lourenço, S. O., Barbarino, E., De-Paula, J. C., Pereira, L. O. \& Lanfer Marquez, U. M. 2002. Amino acid composition, protein content and calculation of nitrogen-to-protein conversion factors for 19 tropical seaweeds. Phycol. Res. 50:233-241.

Lourenço, S. O., Barbarino, E., Lanfer Marquez, U. M. \& Aidar, E. 1998. Distribution of intracellular nitrogen in marine microalgae: basis for the calculation of specific nitrogen-to-protein conversion factors. J. Phycol. 34:798-811.

MacArtain, P., Gill, C. I. R., Brooks, M., Campbell, R. \& Rowland, I. R. 2007. Nutritional value of edible seaweeds Nutr. Rev. 65:535-543.

Maehre, H. K., Malde, M. K., Eilersten, K. E. \& Elvevoll, E. O. 2014. Characterization of protein, lipid and mineral contents in common Norwegian seaweeds and evaluation of their potential as food and feed. J. Sci. Food Agric. 94:3281-3290.

Mariotti, F., Tomé, D. \& Mirand, P. P. 2008. Converting nitrogen into protein: beyond 6.25 and Jones' factors. Crit. Rev. Food Sci. 48:177-184.

Maynard, D. J., Flagg, T. A., McAuley, W. C., Frost, D. A., Kluver, B., Wastel, M. R., Colt, J. E. \& Dickhoff, W. W. 2012. Fish culture technology and practices for captive broodstock rearing of ESA-listed salmon stocks. NOAA Technical Memorandum NMFS-NWFSC-117. National Marine Fisheries Service, Seattle, WA, 65 pp.

McCusker, S., Buff, P. R., Yu, Z. \& Fascetti, A. J. 2014. Amino acid content of selected plant, algae and insect species: a search for alternative protein sources for use in pet foods. J. Nutr. Sci. 3:e39.

McHugh, D. J. 2003. A guide to the seaweed industry. FAO Fisheries Technical Paper 441. Food and Agriculture Organization of the United Nations, Rome, 105 pp.

Morgan, K. C., Wright, J. L. C. \& Simpson, F. J. 1980. Review of chemical constituents of the red alga Palmaria palmata (dulse). Econ. Bot. 34:27-50.

Nelson, M. M., Phleger, C. F. \& Nichols, P. D. 2002. Seasonal lipid composition in macroalgae of the Northeastern
Pacific ocean. Bot. Mar. 45:58-65.

Neori, A., Ragg, N. L. C. \& Shpigel, M. 1998. The integrated culture of seaweed, abalone, fish and clams in modular intensive land-based systems: II. Performance and nitrogen partitioning within an abalone (Haliotis tuberculata) and macroalgae culture system. Aquac. Eng. 17:215-239.

Pang, S. \& Lüning, K. 2004. Tank cultivation of the red algae Palmaria palmata: effects of intermittent light on growth rate, yield and growth kinetics. J. App. Phycol. 16:93-99.

Pereira, R., Yarish, C. \& Critchley, A. T. 2013. Seaweed aquaculture for human foods in land-based and IMTA systems. In Christou, P. (Ed.) Sustainable Food Production. Springer Science, New York, pp. 1405-1424.

Polat, S. \& Ozogul, Y. 2013. Seasonal proximate and fatty acid variations of some seaweeds from the northeastern Mediterranean coast. Oceanologia 55:375-391.

Rautenberger, R., Fernández, P. A., Strittmatter, M., Heesch, S., Cornwall, C. E., Hurd, C. L. \& Roleda, M. Y. 2015. Saturating light and not increased carbon dioxide under ocean acidification drives photosynthesis and growth in Ulva rigida (Chlorophyta). Ecol. Evol. 5:874-888.

Rebours, C., Marinho-Soriano, E., Zertuche-González, J. A., Hayashi, L., Vásquez, J. A., Kradolfer, P., Soriano, G., Ugarte, R., Abreu, M. H., Bay-Larsen, I., Hovelsrud, G., Rødven, R. \& Robledo, D. 2014. Seaweeds: an opportunity for wealth and sustainable livelihood for coastal communities. J. Appl. Phycol. 26:1939-1951.

Renaud, S. M. \& Luong-Van, J. T. 2006. Seasonal variation in the chemical composition of tropical Australian marine macroalgae. J. Appl. Phycol. 18:381-387.

Robertson-Andersson, D. V., Potgieter, M., Hansen, J., Bolton, J. J., Troell, M., Anderson, R. J., Halling, C. \& Probyn, T. 2008. Integrated seaweed cultivation on an abalone farm in South Africa. J. Appl. Phycol. 20:579-595.

Rosen, G., Langdon, C. J. \& Evans, F. 2000. The nutritional value of Palmaria mollis cultured under different light intensities and water exchange rates for juvenile red abalone Haliotis refescens. Aquaculture 185:121-136.

Saunders, G. W. \& Kucera, H. 2010. An evaluation of $r b c \mathrm{~L}$, tufA, UPA, LSU and ITS as DNA barcode markers for the marine green macroalgae. Cryptogam. Algol. 31:487528.

Saunders, G. W. \& McDevit, D. C. 2012. Methods for DNA barcoding photosynthetic protists emphasizing the macroalgae and diatoms. Methods Mol. Biol. 858:207-222.

Saunders, G. W. \& Moore, T. E. 2013. Refinements for the amplification and sequencing of red algal DNA barcode and RedToL phylogenetic markers: a summary of cur- 
rent primers, profiles and strategies. Algae 28:31-43.

Sloan, C. A., Anulacion, B. F., Baugh, K. A., Bolton, J. L., Boyd, D., Boyer, R. H., Burrows, D. G., Herman, D. P., Pearce, R. W. \& Ylitalo, G. M. 2014. Northwest Fisheries Science Center's analyses of tissue, sediment, and water samples for organic contaminants by gas chromatography/mass spectrometry and analyses of tissue for lipid classes by thin layer chromatography/flame ionization detection. NOAA Technical Memorandum NMFS-NWFSC-125. U.S. Department of Commerce, Rockville, MD, $61 \mathrm{pp}$.

Sloan, C. A., Brown, D. W., Ylitalo, G. M., Buzitis, J., Herman, D. P., Burrows, D. G., Yanagida, K., Pearce, R. W., Bolton, J. L., Boyer, R. H. \& Krahn, M. M. 2006. Quality assurance plan for analyses of environmental samples for polycyclic aromatic compounds, persistent organic pollutants, fatty acids, stable isotope ratios, lipid classes, and metabolites of polycyclic aromatic compounds. NOAA Technical Memorandum NMFS-NWFSC-77. U.S. Department of Commerce, Rockville, MD, 30 pp.

Smith, J. L., Summers, G. \& Wong, R. 2010. Nutrient and heavy metal content of edible seaweeds in New Zealand. N. Z. J. Crop. Hortic. Sci. 38:19-28.

Timeanddate.com. 2014. Seattle, Washington, USA: sunrise, sunset, and daylength. Available from: http://www. timeanddate.com/sun/usa/seattle. Accessed Aug 14, 2014.

United States Department of Agriculture. 2016. Crop Production 2015 Summary. Available from: http://www. usda.gov/nass/PUBS/TODAYRPT/cropan16.pdf. Accessed Jun 1, 2016.

Waaland, J. R. 2004. Integrating intensive aquaculture of the red seaweed Chondracanthus exasperatus. Bull. Fish. Res. Agency Suppl. 1:91-100.

Walkiw, O. \& Douglas, D. E. 1975. Health food supplements prepared from kelp: a source of elevated urinary arsenic. Clin. Toxicol. 8:325-331.

Werner, A. \& Dring, M. 2011. Aquaculture explained, No. 27. Cultivating Palmaria palmata. Irish Sea Fisheries Board, Dublin, 74 pp.

Williams, L. G. \& Krueger, C. 1988. Health risk assessment of chemical contamination in Puget Sound seafood. Prepared for U.S. Environmental Protection Agency, Region 10. PB-89-200240/XAB, Tetra Tech Inc., Bellevue, WA, 704 pp.

Yong, Y. S., Yong, W. T. L. \& Anton, A. 2013. Analysis of formulae for determination of seaweed growth rate. J. Appl. Phycol. 25:1831-1834. 